\title{
Glucagon-like peptide-1 (GLP-1) and protective effects in cardiovascular disease: a new therapeutic approach for myocardial protection
}

\author{
Ting C Zhao
}

\begin{abstract}
Glucagon-like peptide-1 (GLP-1) is a member of the proglucagon incretin family implicated in the control of appetite and satiety. GLP-1 has insulinotropic, insulinomimetic, and glucagonostatic effects, thereby exerting multiple complementary actions to lower blood glucose in subjects with type 2 diabetes mellitus. A major advantage over conventional insulin is the fact that the insulinotropic actions of GLP-1 are dependent upon ambient glucose concentration, mitigating the risks of hypoglycemia. Recently, the crucial role of GLP-1 in cardiovascular disease has been suggested in both preclinical and clinical studies. The experimental data indicate GLP-1 and its analogs to have direct effects on the cardiovascular system, in addition to their classic glucoregulatory actions. Clinically, beneficial effects of GLP-1 have also been demonstrated in patients with myocardial ischemia and heart failure. GLP-1 has recently been demonstrated to be a more effective alternative in treating myocardial injury. This paper provides a review on the current evidence supporting the use of GLP-1 in experimental animal models and human trials with the ischemic and non-ischemic heart and discusses their molecular mechanisms and potential as a new therapeutic approach.
\end{abstract}

Keywords: GLP-1, Insulin resistance, Heart, Cardiovascular disease, Diabetes

\section{Introduction}

Myocardial infarction contributes significantly to deaths related to coronary artery disease [1]. Diabetes mellitus threatens to become a global health crisis; treatment of diabetes and its implications constitutes a major health care expenditure. A significant proportion of diabetic patients are known to develop diabetic cardiomyopathy, with a high incidence of congestive heart failure. The continuous requirement for high-energy phosphates to perform mechanical work burdens the heart as metabolic requirements not shared by other organ system. Accordingly, substrate availability, oxidative phosphorylation, and high-energy phosphate transfer are critical to cardiac performance. While the heart is capable of utilizing a variety of available substrates to generate adenosine triphosphate, this metabolic flexibility is compromised

\footnotetext{
Correspondence: tzhao@bu.edu
Cardiovascular Research laboratory, Department of Surgery, Roger Williams

Correspondence: tzhao@bu.edu
Cardiovascular Research laboratory, Department of Surgery, Roger Williams Medical Center, Boston University Medical School, 50 Maude Street, Providence, RI 02908, USA
}

under circumstances in which the heart is stressed, particularly by myocardial ischemia.

Diabetes causes suppressed glucose oxidation leading to inefficient energy production, enhanced fatty acid metabolism, and increased susceptibility to myocardial ischemia and reperfusion injury. In the ischemic myocardium, an increase in glucose uptake and subsequent ATP generated through glycolysis helps to sustain myocardial electric and mechanical performance, maintains cellular ultrastructure, promotes myocardial recovery. Accordingly, mechanism of enhancing myocardial energetic efficiency by stimulating glucose availability and utilization has led to the vigorous pursuit of therapeutic approaches designed to augment glucose uptake and oxidation. Although many therapeutic agents such as $\beta$-blockers and angiotensin-converting enzyme inhibitors are currently used to control cardiovascular diseases (CVD), there remains a substantially high incidence of CVD among diabetic patients, necessitating alternative strategies of targeted management [2]. One such area of interest is the ability to modulate myocardial glucose uptake and its

\section{Biomed Central}

(c) 2013 Zhao; licensee BioMed Central Ltd. This is an Open Access article distributed under the terms of the Creative Commons Attribution License (http://creativecommons.org/licenses/by/2.0), which permits unrestricted use, distribution, and reproduction in any medium, provided the original work is properly cited. 
impact on cardioprotection. Heart failure and myocardial infarction are insulin-resistant states that are associated with a significant risk for either concurrently having or subsequently developing newly-onset diabetes [3]. Insulin resistance is implicated in several potential adverse metabolic changes, including disturbances in insulin and glucose metabolism, which can affect energy supply and blood flow [4]. The injured myocardium develops an evolving dependence on glucose as its preferred metabolic substrate while development of myocardial insulin resistance is associated with the progression of heart failure and increased incidence as well as severity of the damaged hearts.

Insulin, glucose and potassium (GIK) are touted as useful metabolic adjuvant, associated with improvement of cardiac function in acute myocardial function, but the general acceptance of this therapeutic approach is limited by requirements for concomitant infusion of glucose and concerns regarding hypoglycemia. Glucagon-like peptide-1 (GLP-1) is a naturally occurring incretin that is implicated in the control of appetite and satiety. GLP1 has been studied extensively in type 2 diabetes as a novel insulinotropic peptide whose actions are predicated upon the ambient glucose concentration. The experimental studies and clinical data demonstrated that utilizing GLP-1 as a treatment in patients with heart failure improved cardiac function. We and others further have shown that GLP-1 protected the heart against ischemic injury. In this brief review, we will summarize recent progress about the promising role of GLP-1 in myocardial protection and signaling pathway.

\section{GLP-1 and its biological role}

Glucagon-like peptide-1 (GLP-1) is a member of the pro-glucagon incretin family implicated in the control of appetite and satiety [5]. GLP-1 acts through GLP-1 receptor (GLP-1R), a 463 amino-acid member of the G protein-coupled receptor (GPCR) superfamily [6]. Bioactive GLP-1 exists in two equipotent molecular forms: GLP-1 $1^{7-37}$ and GLP-1 ${ }^{7-36}$ amide . GLP-1 is rapidly cleaved by DP IV, which results in the generation of largely inactive molecular GLP-1 ${ }^{9-36}$ amide and GLP-1 ${ }^{7-37}$ forms. The majority of GLP-1 leaving the intestinal venous circulation has already been cleaved by DP IV expressed in capillary surrounding gut L cells, which provides an estimated half-life of 1-2 minutes for intact GLP-1 in vivo [7]. The GLP-1 receptor is widely distributed in tissues, including brain, pancreas, intestine, lung, stomach, and kidney. The effects of GLP-1 appear to be both insulinotropic and insulinomimetic, depending on the ambient glucose concentration. GLP-1 is studied extensively in type 2 diabetes as a novel insulinotropic peptide whose actions are predicated upon the ambient glucose concentration. The actions of GLP-1 to stimulate pancreatic insulin release are attenuated at a glucose concentration less than 4 mmolar. In addition, GLP-1 also exerts actions independent of insulin secretion, such as inhibiting glucagon secretion, gastric emptying, and gastric acid secretion while reducing food intake after both intracerebroventricular and peripheral administration [8]. There is accumulated evidence showing that administration of GLP-1 agonists promotes differentiation of functional $\beta$ cells both in vitro and in vivo $[9,10]$. Furthermore, administration of extendin-4 in the neonatal period to rats following induction of experimental intrauterine growth retardation is associated with a reduced incidence of diabetes due to increased $\beta$-cell mass cell proliferation [11]. Mechanisms of GLP-1 in the regulation of $\beta$-cell mass remain unclear, but may involve MAP kinase, PKC and phosphatidylinositol-3 kinase.

In addition, evidence suggests that GLP-1 acting outside of the pancreas is also important for regulation of glucose metabolism. GLP-1 also has been shown to stimulate glucose disposal via an insulinindependent mechanism(s) [12]. Myocardial receptors for GLP-1 are identified in rodents and human myocardium [13,14]. Although receptors for GLP-1 are found in a variety of tissues including the heart, current evidence exists mainly to support the role of GLP as a modulator of pancreatic hormone release [15]. GLP-1 has been administered as a continuous infusion in type 2 diabetics with impressive insulin-sensitizing effects, reduced insulin resistance in skeletal muscle and adipose tissue, and improvements in insulin-mediated glucose uptake.

\section{Insulin resistance in myocardium}

Insulin resistance is commonly defined as a decreased response of glucose uptake to the stimulatory effect of insulin [16]. Glucose is an especially important substrate for the heart [17], and influences both normal cardiac function and the response of the heart to ischemia that promotes glucose uptake and decreases the utilization of free fatty acids by the human heart [18]. A decrease in glycolysis has been shown in various animal models of heart failure, and heart failure is linked with insulin resistance. On the other hand, patients with chronic heart failure due to coronary artery disease are more likely to have abnormalities in glucose metabolism than are patients with congestive heart failure (CHF) due to idiopathic dilated cardiomyopathy [19]. It has been demonstrated that in patients with myocardial infarction, metabolic syndrome and diabetes were highly prevalent and associated with higher risks of deaths and major cardiovascular events [20]. In addition, euglycaemic hyperinsulinaemic clamp techniques reveal that insulinstimulated glucose uptakes was $20 \%$ lower in congestive 
heart failure patients versus healthy subjects. This is further extended by clinical finding showing that CHF is associated with marked insulin resistance, characterized by both fasting and stimulated hyperinsulinemia. Using laboratory experimental rat myocardial infarction, Clarke's group has demonstrated that insulin-stimulated $\mathrm{D}\left[2-{ }^{3} \mathrm{H}\right]$ glucose uptake was $42 \%$ lower in isolated perfused infarcted hearts, was and this was accompanied by a decrease in expression of glucose transporter (GLUT-4), and negatively correlated with ejection fraction and with fasting plasma FFA concentration [21]. Notably, low glucose uptake in chronic myocardial infarction was also directly in line with a three-fold faster ATP hydrolysis rate, measured using phosphorus-31 magnetic resonance spectroscopy.

\section{Experimental studies of GLP-1 in myocardial protection}

A plethora of experimental data has been generated concerning a role of GLP-1 in diabetes, but very limited evidence has focused on its cardiovascular effect. Both GLP-1(7-36) amide and the GLP-1 receptor agonist, exendin- 4 are shown to increase heart rate and blood pressure in both anesthetized and conscious restrained rats, although the mechanisms are controversial [22,23]. In vitro studies have failed to show any effects of GLP-1 on cardiac myocyte contractility. Very recently, promising clinical data from Shannon's lab showed that GLP-1 infusion improved regional and global function in patients with acute myocardial ischemia and severe systolic dysfunction after successful primary angioplasty [24]. Furthermore, in pacing-induced heart failure model, the stimulation of GLP signaling with GLP-1 has also been demonstrated to improve cardiac performance in conscious dogs with dilated cardiomyopathy [25]. Infusion of GLP-1 was associated with a marked improvement in LV systolic function and diastolic function in decompensated heart failure. By using established isovolumetric isolated perfused rat hearts, we observed that activation of GLP-1 receptor with GLP-1 significantly mitigated myocardial injury as indicated by an improvement in recovery of developed pressure and end-diastolic pressure as well as rate pressure products [26]. Moreover, post-ischemic myocardial improvement was accompanied by a significant reduction in myocardial necrosis. GLP-1 caused an increase in myocardial glucose uptake in isolated hearts, which was in agreement with a previous study in which the GLP-1 promoted myocardial glucose uptake in conscious dogs with pacing induced dilated cardiomyopathy [25]. This may reflect a fact that the protective effect of GLP-1 on ischemic heart was attributed to overcoming insulin resistance under ischemic conditions. In agreement with our studies, evidence from Yellon's observations suggests that GLP-1 added before ischemia induced a significant reduction of infarct size as compared to the control group. However, this protection was abrogated by administration of GLP-1 antagonist exendin (9-39) and inhibition of PI3 kinase [27]. However, Kavianpour et al. reported that GLP-1 (7-36) was not found to alter myocardial glucose utilization; hemodynamic variables and consequent infarction changed in porcin myocardium despite GLP-1 increased insulin secretion and decreased blood uptake [28]. The discrepancies of GLP-1 in these studies definitely depend on the model (in vivo/in vitro), species, and the duration of GLP-1 (short/sustained half life). Native GLP-1 is rapidly degraded by dipeptidyl peptidase-IV (DPP-IV) in the blood stream. Accordingly, the direct cardiovascular response of GLP-1 may be masked by the effective fragments under in vivo conditions [29].

\section{Clinical studies of GLP-1 in patients}

The promising data obtained in experimental studies suggest that the therapeutic strategies based on incretins may preserve cardiomyocyte viability, increase metabolic efficiency, and inhibit the structural and functional remodeling that occurs in the ischemic and the failing heart. Against the backdrop of an expansive body of evidence indicating salutary cardiovascular effects of GLP-1 in the experimental animal model, there have been several phase 2 trials of GLP- 1 in humans with cardiovascular diseases $[5,24,30]$. Shannon's group is the first to demonstrate that infusion of GLP-1(7-36) $(1.5 \mathrm{pmol} / \mathrm{kg} / \mathrm{min})$ for $72 \mathrm{hr}$ in patients with left ventricular dysfunction after MI improved global and regional left ventricular wall motion scores and reduced hospital stay and in-hospital mortality. These effects remain detectable even several weeks after hospital discharge [5]. The benefits of GLP-1 on LVEF were evident in both diabetic and non-diabetic patients, as well as in patients with anterior (left anterior descending artery) and non-anterior AMI. Sokos et al. reported that a long-term infusion of GLP-1 improves both LVEF and functional capacity in human patients with advanced heart failure [30]. In a single-center pilot study, 20 obese patients with $\mathrm{LVEF} \leq 40 \%$ and NYHA class III or IV heart failure were divided to receive a continuous subcutaneous infusion of GLP-1 or a small volume of saline as a control over 5 weeks. All patients in the study were on a standard, stable heart failure medication regimen. The group treated with GLP-1 had significantly improved LVEF, maximum myocardial ventilation oxygen consumption, 6-minute walk distance and Minnesota Living with Heart failure Quality of Life scores. GLP-1 also led to improved glycemic control with an increase in plasma insulin and decrease in plasma NEFA levels. The promising results from the above clinical studies were further corroborated with additional recent data obtained in a pilot study performed in 20 patients after percutaneous coronary intervention confirming the cardioprotective effects of GLP-1, ameliorating left ventricular dysfunction after 
the ischemic event [31]. Another pilot study showed that treatment with GLP-1 (7-36) $(1.2 \mathrm{pmol} / \mathrm{kg} / \mathrm{min})$ improved left ventricular function in response to stress in 14 patients with coronary artery disease (CAD) [32]. This observation was furthered supported with an additional report that 172 patients treated with exenatide $(0.12 \mu \mathrm{g} / \mathrm{min})$ for $6 \mathrm{hr}$ after ST-Segment elevation MI exhibited a significant increase in myocardial salvage when compared with the placebo group.

\section{Anti-hypertensive effect of GLP-1}

The cardioprotective effects of GLP-1 have also been reported in the in vivo hypertension animal models in which GLP-1 significantly improved the survival rates of the Spontaneously Hypertensive, Heart Failure-prone (SHHF) rats that demonstrated preserved LV function and LV mass index [33]. Such anti-hypertentive action has been demonstrated in Dahl salt-sensitive (DSS) rats in which continuous administration of recombinant GLP-1 attenuated the development of hypertension [34]. The prevention of hypertension by GLP-1 was directly linked to decreased LV hypotrophy in DSS as well as higher levels of urine flow and sodium excretion, contributing to the comprehensive anti-hypertension effects of GLP-1. Liu Q et al. reported that treatment of AC3174, an exenatide-related GLP-1R agonist, antagonized the hypertensive effect and prevented the development of cardiac hypertrophy in DSS model [35]. These data were further confirmed by the observations that inhibition of DPP-4 through the administration of Sitagliptin to increase the level of biologically active intact GLP-1 significantly attenuated high blood pressure in young pre-hypertensive spontaneously hypertensive rats (SHRs) [36]. Additionally, function and expression of $\mathrm{Na} / \mathrm{H}$ exchanger isoform 3 (NHE3) decreased but there was increased urine flow and sodium excretion in the tested young SHRs. Pooled data from six trials showed that 6 months of exenatide treatment significantly reduced systolic blood pressure in patients with type 2 diabetes [37]. Liraglutide was evaluated in a series of phase 3 trials and it demonstrated a promising anti-systolic blood pressure effect in combination with other anti-diabetes drugs like metformin [38]. Using transgenic mouse model, it has recently been demonstrated that that cardiac GLP-1R activation promotes the secretion of atrial natriuretic peptide (ANP) and a reduction of blood pressure. LGLP-1R agonist liraglutide did not result in ANP secretion, vasorelaxation, or lower blood pressure in Glp1rdeficient mice, revealing a gut-heart GLP-1R-dependent and ANPdependent axis that regulates blood pressure [39].

\section{GLP-1 and anti-obese effects}

The last few decades have witnessed a global rise in adult obesity of epidemic proportions. The potential impact of this is emphasized when one considers that body mass index (BMI) is a powerful predictor of death, type 2 diabetes (T2DM), and cardiovascular morbidity and mortality [40]. Weight gain and obesity are associated with structural and functional changes of the cardiovascular system including left atrial and ventricular remodeling, hemodynamic alterations, autonomic dysfunction, and diastolic dysfunction. Moreover, diabetic cardiomyopathy is characterized by an adverse structural and functional cardiac phenotype [41]. For persons with diabetes or obesity, the chief goal is to avoid the common cardiovascular sequelae. In past years, numerous drugs have been approved for treatment of obesity. However, most of them are withdrawn from the market because of their adverse effects. $\mathrm{Li} \mathrm{C}$ et al. observed that Addition of liraglutide to abdominally obese, insulintreated patients led to improvement in glycemic control similar to that achieved by increasing insulin dosage [42]. Adding liraglutide to insulin also induced a significant reduction in body weight and waist circumference, suggesting that Liraglutide may be the best treatment option for poorly controlled type 2 Diabetes and abdominal obesity. In agreement with this evidence, Fujishima et al., demonstrated that Liraglutide improved visceral fat adiposity, produced meaningful weight loss, and significantly improved eating behavior in obese Japanese patients with type 2 diabetes. The effect of GLP-1 receptor agonist treatment on endothelial function has not been well-described in humans $[43,44]$. Kelly et al. demonstrated that three months of therapy through GLP-1 agonists (exenatide vs metformin) exerted similar effects on microvascular endothelial function, inflammation, oxidative stress, and vascular activation in patients with obesity and pre-diabetes [45].

\section{Signaling pathway involved by GLP-1 in myocardial protection}

We observed abundant expression of GLP-1 receptors in the rat myocardium. However, the mechanisms whereby GLP-1 receptors couple to intracellular effectors in extrapancretic tissues, such as the heart, remain largely unexplored. In turn, we observed that GLP-1 and insulin had comparable effects on myocardial glucose uptake, but via different cellular mechanisms. We have found that p38 mitogen-activated protein kinase serves as an important mechanism through which GLP-1 modulates myocardial injury. In addition, the co-ordination between PI3K and nitric oxides in modulating cardiac function has recently been established.

\section{The mitogen-activated protein kinases (MAPKs)}

MAPKs play a central role in the transmission of signals from cell surface receptors and various environmental cues to the transcriptional machinery in the nucleus 
involved in cell growth, differentiation, and transformation $[46,47]$. Several distinct MAPK subfamilies have been characterized in cardiac tissue, including the p38 MAP kinase, the stressed-activated protein kinase/c-Jun N-terminal kinase (JUN kinase), the extracellularresponsive kinase (ERKS), big MAPK-1(ERK5) [48]. p38 can be activated by various stresses including cytokines and $I / R$ [49]. p38 has been shown to be protective in several models [50]. The p38 family of mitogen-activated protein kinases has been shown to play an important role in mediating stress-induced signaling in mammalian cells. There are two predominant isoforms of p38 in heart, $\alpha$ and $\beta$. Overexpression of p38 $\beta$ has been shown to induce hypertrophic responses and to promote survival of myocytes, whereas activation of p38 $\alpha$ antagonizes these effects and leads to cell death [51].

Our previous studies showed that activation of p38 protected the heart against $I / R$ injury [52]. In line with our observation, activation of $\mathrm{p} 38$ with preconditioning stimuli or over-expression of MKK3/MKK6 has been reported to protect the heart against myocardial I/R injury [53-58]. Mutation of p38 $\beta$ isoform also resulted in increased myocardial injury [59]. However, during lethal ischemia, ischemia and reperfusion as well as postconditioning p38 inhibition has been shown to result in protection [60,61]. Transgenic mice expressing a cardiac dominant-negative (Dn) p38 $\alpha$ antagonized cardiac I/R injury, and disruption of a single copy of p38 $\alpha$ in mice was reported to be less susceptible to myocardial I/R injury $[62,63]$. Dominant negative over-expression of p38 $\alpha$ transgenic mice show enhanced cardiac hypertrophy following aortic banding [64]. Dn-p38 $\alpha$ mice had a markedly reduced infarct size and increased ventricular systolic function flowing chronic infarction [65]. These conflicts remain unclear. These discrepancies may be explained by strength of p38 activation and activation of different isoforms, vastly different stress conditions, and animal species [66-68]. During low flow ischemia, we documented that both GLP-1 and insulin-mediated glucose uptake did not involve Akt-1 activation in the postischemic myocardium [26]. It is intriguing to reveal from our recent observation that GLP-1 was associated with increased p38 activities. However, based on our current studies, it remains unknown if these unique signaling components are only epiphenomenon or crucial for GLP-1 to play a protective effect. If so, what p38 isoform/nitric oxide synthase would be dominant in regulation of cardioprotection afforded by GLP-1.

\section{$\mathrm{PI} 3 \mathrm{~K}$ and nitric oxides}

The importance of p38/nitric oxide has been addressed based on our recent findings [52]. Inhibitors of PI3K and p42/44 mitogen-activated protein kinase (LY294002 and UO126), respectively as well as of p70S6K rapamycin abolished the GLP-1-induced infarct size limitation in rat hearts, suggesting that PI3K and p42/44 are involved in the myocardial protection elicited by GLP-1 $[27,69]$. These results indicate GLP-mediated activation of reperfusion injury salvages kinase pathway, reminiscent of the GLP-1 coupling to PI3K-akt-signlaing in insulinproducing cells [70]. In addition, insulin mediated glucose uptake was associated with Akt-1 phosphorylation and GLUT 4 translocation [26]. In contrast, GLP-1 did not increase Akt-1 phosphorylation and GLUT 4 translocation, but did result in increased GLUT 1 expression in the sarcolemma. Administration of $\mathrm{L}-\mathrm{N}^{\mathrm{G}}$-Nitroarginine Methyl Ester (L-NAME) attenuated this protective effect in mouse model [71], pointing to GLP-1-mediated cardioprotection through modulation of nitric oxides. Some studies also reveal that GLP-1 has a dose-dependent vasorelaxant effect, which is mediated by both endothelium and nitric oxide [71,72]. Golpon et al. showed that
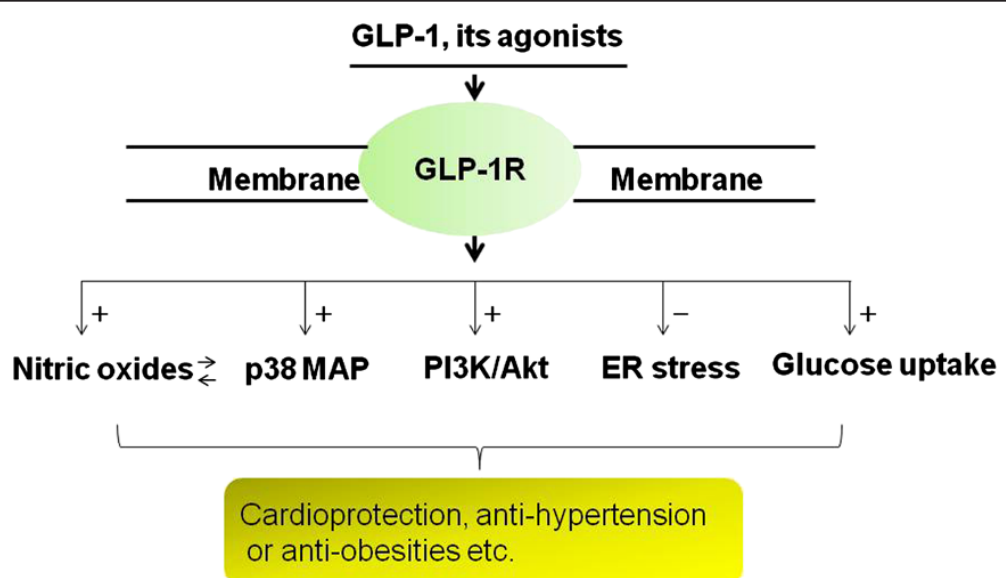

Figure 1 Proposed signaling pathways induced by GLP-1. GLP-1: glucagon-like peptide-1; GLP-1R: glucagon-like peptide-1 receptor; p38 MAPK: p38 mitogen-activated protein kinase; PI3K: phosphatidylinositide 3-kinase; ER: endoplasmic reticulum. 
NG-nitro-Larginine methyl ester treatment inhibits endothelial NOS (eNOS) abolished GLP-1 mediated vasorelaxation of rat pulmonary arteries [72]. In addition, other studies suggested that the vasorelaxant effects of GLP-1 were mediated by activation of AMP or KATP channels independently of nitric oxide and the endothelium $[73,74]$. GLP-1-activated pathway uses cyclic adenosine monophosphate (cAMP) in insulin producing cells [70], and a cAMP-dependent pathway would be essential for the pro-survival action of GLP-1 in the heart [27]. GLP-1mediated stimulation of cAMP in cardiac myocytes has been demonstrated [13].

\section{Other signaling pathways}

The endoplasmic reticulum (ER) is a multifunctional organelle responsible for the synthesis and folding of proteins as well as calcium storage and signaling. Perturbations of ER function cause ER stress leading to the unfolded protein response, which includes inhibition of protein synthesis, protein refolding, and clearance of misfolded proteins [75]. Growing evidence links the ER to pathologies such as diabetes mellitus, obesity, liver, heart, renal and neurodegenerative diseases, endothelial dysfunction, atherosclerosis, and cancer [76]. Recent discoveries regarding the role of inflammation, mitochondrial dysfunction, and ER stress in obesity have advanced our understanding of how insulin resistance develops in peripheral organs [77]. A recent observation using a diabetic cardiomyopathy rat model reveals that the GLP-1 analog liraglutide improved cardiac function, which is accompanied with a decrease in activating transcription factor 4 (ATF4) and TNF receptor associated factor 2 (TRAF2) and the down-regulation of Grp78 and caspase-3. This suggests that GLP-1-induced cardioprotection may be related to the inactivation of the ER stress signaling pathway [78].

\section{Conclusion}

GLP-1 recently attracted attention as a therapeutic strategy for diabetes, heart diseases, and obesity. Metabolic modulation of post-ischemic myocardium and advanced left ventricular dysfunction is an important and emerging area of therapeutic investigation. Conventional approaches using insulin have been proven ineffective, development of new strategies to promote glucose uptake is a promising initiative. We and others have established the significance of GLP-1 in protect the heart against acute myocardial ischemic injury. Recently, a significant number of studies have indicated beneficial effects of GLP-1 on cardiovascular function, which appears to justify the usage of GLP-1 in the treatment of cardiovascular diseases. Exploration of its downstream signaling pathway using integrative molecular and cellular approaches and evaluation of its clinical outcome will provide direct evidence to support potential clinical implication (summarized in Figure 1).

\section{Competing interests}

The author declares that he has no competing interest.

\section{Acknowledgments}

The work is supported by the National Heart, Lung, and Blood Institute Grant (R01 HL089405) and American Heart Association-National center (0735458 N) to TCZ.

Received: 19 April 2013 Accepted: 5 June 2013

Published: 18 June 2013

\section{References}

1. Phillips K, Luk A, Soor GS, Abraham JR, Leong S, Butany J: Cocaine cardiotoxicity: a review of the pathophysiology, pathology, and treatment options. Am J Cardiovasc Drugs 2009, 9(3):177-196.

2. Eltzschig HK, Eckle T: Ischemia and reperfusion-from mechanism to translation. Nat Med 2011, 17(11):1391-1401.

3. Kostis JB, Sanders M: The association of heart failure with insulin resistance and the development of type 2 diabetes. Am J Hypertens 2005, 18(5 Pt 1):731-737

4. Swan JW, Anker SD, Walton C, Godsland IF, Clark AL, Leyva F, Stevenson JC, Coats AJJ: Insulin resistance in chronic heart failure: relation to severity and etiology of heart failure. Am Coll Cardiol 1997, 30(2):527-532.

5. Nikolaidis LA, Mankad S, Sokos GG, Miske G, Shah A, Elahi D, Shannon RP: Effects of glucagon-like peptide-1 in patients with acute myocardial infarction and left ventricular dysfunction after successful reperfusion. Circulation 2004, 109(8):962-965.

6. Drucker DJ: Glucagon-like peptides: regulators of cell proliferation, differentiation, and apoptosis. Mol Endocrinol 2003, 17(2):161-171.

7. Drucker DJ: Biological actions and therapeutic potential of the glucagonlike peptides. Gastroenterology 2002, 122(2):531-544.

8. Gros R, You X, Baggio LL, Kabir MG, Sadi AM, Mungrue IN, Parker TG, Huang Q, Drucker DJ, Husain M: Cardiac function in mice lacking the glucagonlike peptide-1 receptor. Endocrinology 2003, 144(6):2242-2252.

9. Buteau J, Foisy S, Rhodes CJ, Carpenter L, Biden TJ, Prentki M: Protein kinase Czeta activation mediates glucagon-like peptide-1-induced pancreatic beta-cell proliferation. Diabetes 2001, 50(10):2237-2243.

10. Friedrichsen BN, Neubauer N, Lee YC, Gram VK, Blume N, Petersen JS, Nielsen JH, Møldrup A: Stimulation of pancreatic beta-cell replication by incretins involves transcriptional induction of cyclin D1 via multiple signalling pathways. J Endocrinol 2006, 188(3):481-492.

11. Stoffers DA, Desai BM, DeLeon DD, Simmons RA: Neonatal exendin-4 prevents the development of diabetes in the intrauterine growth retarded rat. Diabetes 2003, 52(3):734-740.

12. Bullock BP, Heller RS, Habener JF: Tissue distribution of messenger ribonucleic acid encoding the rat glucagon-like peptide-1 receptor. Endocrinology 1996, 137(7):2968-2978.

13. Vila Petroff MG, Egan JM, Wang X, Sollott SJ: Glucagon-like peptide-1 increases CAMP but fails to augment contraction in adult rat cardiac myocytes. Circ Res 2001, 89(5):445-452.

14. Wei Y, Mojsov S: Tissue-specific expression of the human receptor for glucagon-like peptide-l: brain, heart and pancreatic forms have the same deduced amino acid sequences. FEBS Lett 1995, 358(3):219-224.

15. Brubaker PL, Drucker DJ: Glucagon-like peptides regulate cell proliferation and apoptosis in the pancreas, gut, and central nervous system. Endocrinology 2004, 145(6):2653-2659.

16. Reaven GM: Role of insulin resistance in human disease. Diabetes 1988, 37:1595-1607.

17. Opie LH: The heart, physiology and metabolism. New York: Raven; 1991

18. Oliver MF, Opie LH: Effects of glucose and fatty acids on myocardial ischaemia and arrhythmias. Lancet 1994, 343:155-158.

19. Swan JW, Anker SD, Walton C, Godsland IF, Clark AL, Leyva F, Stevenson JC, Coats AJ: Insulin resistance in chronic heart failure: relation to severity and etiology of heart failure. J Am Coll Cardiol 1997, 30(2):527-532.

20. Levantesi G, Macchia A, Marfisi RM, Franzosi MG, Maggioni AP, Nicolosi GL, Schweiger C, Tavazzi L, Tognoni G, Valagussa F, Marchioli R, on behalf of the GISSI-Prevenzione Investigators: Metabolic syndrome and risk of 
cardiovascular events after myocardial infarction. J Am Coll Cardiol 2005, 46:277-283.

21. Paternostro G, Clarke K, Heath J, Seymour AM, Radda GK: Decreased GLUT-4 mRNA content and insulin-sensitive deoxyglucose uptake show insulin resistance in the hypertensive rat heart. Cardiovasc Res 1995, 30(2):205-211.

22. Yamamoto $H$, Lee CE, Marcus JN, Williams TD, Overton JM, Lopez ME, Hollenberg AN, Baggio L, Saper CB, Drucker DJ, Elmquist JK: Glucagon-like peptide-1 receptor stimulation increases blood pressure and heart rate and activates autonomic regulatory neurons. J Clin Invest 2002, 110(1):43-52.

23. Barragán JM, Rodríguez RE, Eng J, Blázquez E: Interactions of exendin-[9-39] with the effects of glucagon-like peptide-1-[7-36] amide and of exendin-4 on arterial blood pressure and heart rate in rats. Regul Pept 1996 67(1):63-68

24. Sokos GG, Bolukoglu H, German J, Hentosz T, Magovern GJ Jr, Maher TD, Dean DA, Bailey SH, Marrone G, Benckart DH, Elahi D, Shannon RP: Effect of glucagon-like peptide-1 (GLP-1) on glycemic control and left ventricular function in patients undergoing coronary artery bypass grafting. Am J Cardiol 2007, 100(5):824-829.

25. Nikolaidis L, Elahi D, Shen Y, Shannon RP: Active metabolite of GLP-1 mediates myocardial glucose uptake and improves ventricular performance in conscious dogs with dilated cardiomyopathy. Am J Physiol Heart Circ Physiol 2005, 289(6):H2401-H2408.

26. Zhao T, Parikh P, Bhashyam S, Bolukoglu H, Poornima I, Shen YT, Shannon RP: Direct effects of glucagon-like peptide- 1 on myocardial contractility and glucose uptake in normal and postischemic isolated rat hearts. J Pharmacol Exp Ther 2006, 317(3):1106-1113.

27. Bose AK, Mocanu MM, Carr RD, Brand CL, Yellon DM: Glucagon-like peptide 1 can directly protect the heart against ischemia/reperfusion injury. Diabetes 2005, 54(1):146-151.

28. Kavianipour M, Ehlers MR, Malmberg K, Ronquist G, Ryden L, Wikstrom G, Gutniak M: Glucagon-like peptide-1 (7-36) amide prevents the accumulation of pyruvate and lactate in the ischemic and non-ischemic porcine myocardium. Peptides 2003, 24:569-578.

29. Mentlein R, Gallwitz B, Schmidt WE: Dipeptidyl-peptidase IV hydrolyses gastric inhibitory polypeptide, glucagon-like peptide-1(7-36)amide, peptide histidine methionine and is responsible for their degradation in human serum. Eur J Biochem 1993, 214:829-835.

30. Sokos GG, Nikolaidis LA, Mankad S, Elahi D, Shannon RP: Glucagon-like peptide-1 infusion improves left ventricular ejection fraction and functional status in patients with chronic heart failure. J Card Fail 2006, 12(9):694-699.

31. Read PA, Hoole SP, White PA, Khan FZ, O'Sullivan M, West NE, Dutka DP: A pilot study to assess whether glucagon-like peptide- 1 protects the heart from ischemic dysfunction and attenuates stunning after coronary balloon occlusion in humans. Circ Cardiovasc Interv 2011, 4(3):266-272.

32. Read PA, Khan FZ, Dutka DP: Cardioprotection against ischaemia induced by dobutamine stress using glucagon-like peptide- 1 in patients with coronary artery disease. Heart 2012, 98(5):408-413.

33. Poornima I, Brown SB, Bhashyam S, Parikh P, Bolukoglu H, Shannon RP Chronic glucagon-like peptide-1 infusion sustains left ventricular systolic function and prolongs survival in the spontaneously hypertensive, heart failure-prone rat. Circ Heart Fail 2008, 1(3):153-160.

34. Yu M, Moreno C, Hoagland KM, Dahly A, Ditter K, Mistry M, Roman RJ: Antihypertensive effect of glucagon-like peptide 1 in Dahl salt-sensitive rats. J Hypertens 2003, 6:1125-1135.

35. Liu Q, Adams L, Broyde A, Fernandez R, Baron AD, Parkes DG: The exenatide analogue $A C 3174$ attenuates hypertension, insulin resistance, and renal dysfunction in Dahl salt-sensitive rats. Cardiovasc Diabetol 2010, 9(1):32.

36. Pacheco BP, Crajoinas RO, Couto GK, Davel AP, Lessa LM, Rossoni LV, Girardi AC: Dipeptidyl peptidase IV inhibition attenuates blood pressure rising in young spontaneously hypertensive rats. J Hypertens 2011, 29(3):520-528.

37. Okerson T, Yan P, Stonehouse A, Brodows R: Effects of exenatide on systolic blood pressure in subjects with type 2 diabetes. Am J Hypertens 2010, 23(3):334-339.

38. Blonde L, Russell-Jones D: The safety and efficacy of liraglutide with or without oral antidiabetic drug therapy in type 2 diabetes: an overview of the LEAD 1-5 studies. Diabet Obes Metab 2009, 11(suppl3):26-34.

39. Kim M, Platt MJ, Shibasaki T, Quaggin SE, Backx PH, Seino S, Simpson JA, Drucker DJ: GLP-1 receptor activation and Epac2 link atrial natriuretic peptide secretion to control of blood pressure. Nature Med 2013, 19(5):567-575

40. Bender SB, McGraw AP, Jaffe IZ, Sowers JR: Mineralocorticoid receptormediated vascular insulin resistance: an early contributor to diabetesrelated vascular disease? Diabetes 2013, 62(2):313-319.

41. Asghar O, Alam U, Hayat SA, Aghamohammadzadeh R, Heagerty AM, Malik RA: Obesity, diabetes and atrial fibrillation; epidemiology, mechanisms and interventions. Curr Cardiol Rev 2012, 8(4):253-264.

42. Li CJ, Li J, Zhang QM, Lv L, Chen R, LV CF, Yu P, Yu DM: Efficacy and safety comparison between liraglutide as add-on therapy to insulin and insulin dose-increase in Chinese subjects with poorly controlled type 2 diabetes and abdominal obesity. Cardiovasc Diabetol 2012, 11:142.

43. Fujishima Y, Maeda N, Inoue K, Kashine S, Nishizawa H, Hirata A, Kozawa J, Yasuda T, Okita K, Imagawa A, Funahashi T, Shimomura I: Efficacy of liraglutide, a glucagon-like peptide-1 (GLP-1) analogue, on body weight, eating behavior, and glycemic control, in Japanese obese type 2 diabetes. Cardiovasc Diabetol 2012, 11:107.

44. Inoue K, Maeda N, Kashine S, Fujishima Y, Kozawa J, Hiuge-Shimizu A, Okita $K$, Imagawa A, Funahashi T, Shimomura I: Short-term effects of liraglutide on visceral fat adiposity, appetite, and food preference: a pilot study of obese Japanese patients with type 2 diabetes. Cardiovasc Diabetol 2011, 10:109.

45. Kelly AS, Bergenstal RM, Gonzalez-Campoy JM, Katz H, Bank AJ: Effects of exenatide vs. metformin on endothelial function in obese patients with pre-diabetes: a randomized trial. Cardiovasc Diabetol 2012, 11:64.

46. Cobb M, Goldsmith EJ: How MAP kinases are regulated. J Biol Chem 1995, 270:14843-14846

47. Hill CS, Treisman R: Transcriptional regulation by extracellular signals: mechanisms and specificity. Cell 1995, 80:199-211.

48. Rose BA, Force T, Wang Y: Mitogen-activated protein kinase signaling in the heart: angels versus demons in a heart-breaking tale. Physio/ Rev 2010, 90(4):1507-1546.

49. Nishida $E$, Gotoh $Y$ : The MAP kinase cascade is essential for diverse signal transduction pathways. Trends Biochem Sci 1993, 18:128-131.

50. Zhao TC, Hines DS, Kukreja RC: Adenosine-induced late preconditioning in mouse hearts: role of p38 MAP kinase and mitochondrial KATP channels. Am J Physiol Heart Circ Physiol 2001, 280:H1278-H1285.

51. Wang Y, Huang S, Sah VP, Ross J Jr, Brown JH, Han J, Chien KR: Cardiac muscle cell hypertrophy and apoptosis induced by distinct members of the p38 mitogen-activated protein kinase family. J Biol Chem 1998, 273(4):2161-2168.

52. Zhao TC, Taher MM, Valerie KC, Kukreja RC: p38 Triggers late preconditioning elicited by anisomycin in heart: involvement of NF-kappaB and iNOS. Circ Res 2001, 89:915-922.

53. Martindale JJ, Wall JA, Martinez-Longoria DM, Aryal P, Rockman HA, Guo Y, Bolli R, Glembotski CC: Overexpression of mitogen-activated protein kinase kinase 6 in the heart improves functional recovery from ischemia in vitro and protects against myocardial infarction in vivo. $J \mathrm{Bio} / \mathrm{Chem}$ 2005, 280:669-676.

54. Peart JN, Gross ER, Headrick JP, Gross GJ: Impaired p38 MAPK/HSP27 signaling underlies aging-related failure in opioid-mediated cardioprotection. J Mol Cell Cardiol 2007, 42:972-980.

55. Dana A, Skarli M, Papakrivopoulou J, Yellon DM: Adenosine A(1) receptor induced delayed preconditioning in rabbits: induction of p38 mitogenactivated protein kinase activation and Hsp27 phosphorylation via a tyrosine kinase- and protein kinase C-dependent mechanism. Circ Res 2000, 86:989-997.

56. Schulz R, Belosjorow S, Gres P, Jansen J, Michel MC, Heusch G: p38 MAP kinase is a mediator of ischemic preconditioning in pigs. Cardiovasc Res 2002, 55:690-700.

57. Haq SE, Clerk A, Sugden PH: Activation of mitogen-activated protein kinases (p38-MAPKs, SAPKs/JNKs and ERKs) by adenosine in the perfused rat heart. FEBS Lett 1998, 434:305-308.

58. Kabir AM, Cao X, Gorog DA, Tanno M, Bassi R, Bellahcene M, Quinlan RA Davis RJ, Flavell RA, Shattock MJ, Marber MS: Antimycin A induced cardioprotection is dependent on pre-ischemic p38-MAPK activation but independent of MKK3. J Mol Cell Cardiol 2005, 39:709-717.

59. Martin $J \mathrm{~L}$, Avkiran M, Quinlan RA, Cohen P, Marber MS: Antiischemic effects of SB203580 are mediated through the inhibition of p38alpha mitogenactivated protein kinase: Evidence from ectopic expression of an inhibition-resistant kinase. Circ Res 2001, 89:750-752. 
60. Sun HY, Wang NP, Halkos M, Kerendi F, Kin H, Guyton RA, Vinten-Johansen J, Zhao ZQ: Postconditioning attenuates cardiomyocyte apoptosis via inhibition of JNK and p38 mitogen-activated protein kinase signaling pathways. Apoptosis 2006, 11:1583-1593.

61. Ma XL, Kumar S, Louden CS, Lopez BL, Christoper TA, Wang C, Lee JC, Feuerstein GZ, Yue TL: Inhibition of p38 mitogen-activated protein kinase decrease cardiomyocyte apoptosis and improves cardiac function after myocardial ischemia and reperfusion. Circulation 1999, 99:1685-1691.

62. Kaiser RA, Bueno OF, Lips DJ, Doevendans PA, Jones F, Kimball TF, Molkentin JD: Targeted inhibition of p38 mitogen-activated protein kinase antagonizes cardiac injury and cell death following ischemiareperfusion in vivo. J Biol Chem 2004, 279:15524-15530.

63. Otsu K, Yamashita N, Nishida K, Hirotani S, Yamaguchi O, Watanabe T, Hikoso S, Higuchi Y, Matsumura Y, Maruyama M, Sudo T, Osada H, Hori M: Disruption of a single copy of the p38alpha MAP kinase gene leads to cardioprotection against ischemia-reperfusion. Biochem Biophys Res Commun 2003, 302:56-60.

64. Liu J, Sadoshima J, Zhai P, Hong C, Yang G, Chen W, Yan L, Wang Y, Vatner SF, Vatner DE: Pressure overload induces greater hypertrophy and mortality in female mice with p38alpha MAPK inhibition. J Mol Cell Cardiol 2006, 41(4):680-688.

65. Muslin AJ: MAPK signalling in cardiovascular health and disease: molecular mechanisms and therapeutic targets. Clin Sci (Lond) 2008, 115(7):203-218.

66. Ping P, Murphy E: Role of $\mathrm{p} 38$ mitogen-activated protein kinases in preconditioning: a detrimental factor or a protective kinase? Circ Res 2000, 86:921-922.

67. Steenbergen $\mathrm{C}$ : The role of $\mathrm{p} 38$ mitogen-activated protein kinase in myocardial ischemia/reperfusion injury; relationship to ischemic preconditioning. Basic Res Cardiol 2002, 97:276-285.

68. Sugden PH, Clerk A: "Stress-responsive" mitogen-activated protein kinases (c-Jun $\mathrm{N}$-terminal kinases and p38 mitogen-activated protein kinases) in the myocardium. Circ Res 1998, 83:345-352.

69. Bose AK, Mocanu MM, Carr RD, Yellon DM: Myocardial ischaemiareperfusion injury is attenuated by intact glucagon like peptide-1 (GLP-1) in the in vitro rat heart and may involve the p70s6K pathway. Cardiovasc Drugs Ther 2007, 21(4):253-256.

70. Doyle ME, Egan JM: Mechanisms of action of glucagon-like peptide 1 in the pancreas. Pharmacol Ther 2007, 113(3):546-593.

71. Ban K, Noyan-Ashraf MH, Hoefer J, Bolz SS, Drucker DJ, Husain M: Cardioprotective and vasodilatory actions of glucagon-like peptide 1 receptor are mediated through both glucagon-like peptide 1 receptordependent and -independent pathways. Circulation 2008, 117(18):2340-2350

72. Golpon HA, Puechner A, Welte T, Wichert PV, Feddersen CO: Vasorelaxant effect of glucagon-like peptide-(7-36)amide and amylin on the pulmonary circulation of the rat. Regul Pept 2001, 102(2-3):81-86.

73. Green BD, Hand KV, Dougan JE, McDonnell BM, Cassidy RS, Grieve DJ: GLP-1 and related peptides cause concentration-dependent relaxation of rat aorta through a pathway involving KATP and CAMP. Arch Biochem Biophys 2008, 478(2):136-142.

74. Nyström T, Gonon AT, Sjöholm A, Pernow J: Glucagon-like peptide-1 relaxes rat conduit arteries via an endothelium-independent mechanism. Regul Pept 2005, 125(1-3):173-177.

75. Toth A, Nickson P, Mandl A, Bannister ML, Toth K, Erhardt P: Endoplasmic reticulum stress as a novel therapeutic target in heart diseases. Cardiovasc Hematol Disord Drug Targets 2007, 7(3):205-218.

76. Popov D: Endoplasmic reticulum stress and the on site function of resident PTP1B. Biochem Biophys Res Commun 2012, 422(4):535-538.

77. Gray S, Kim JK: New insights into insulin resistance in the diabetic heart. Trends Endocrinol Metab 2011, 22(10):394-403.

78. Liu J, Liu Y, Chen L, Wang Y, Li J: Glucagon-Like peptide-1 analog liraglutide protects against diabetic cardiomyopathy by the inhibition of the endoplasmic reticulum stress pathway. J Diabetes Res 2013, 2013:630537.

doi:10.1186/1475-2840-12-90

Cite this article as: Zhao: Glucagon-like peptide-1 (GLP-1) and protective effects in cardiovascular disease: a new therapeutic approach for myocardial protection. Cardiovascular Diabetology 2013 12:90.

\section{Submit your next manuscript to BioMed Central and take full advantage of:}

- Convenient online submission

- Thorough peer review

- No space constraints or color figure charges

- Immediate publication on acceptance

- Inclusion in PubMed, CAS, Scopus and Google Scholar

- Research which is freely available for redistribution 